\title{
PENGARUH SUBSTITUSI TEPUNG SEKAM PADI \& CASSAVA PADA TEPUNG INDUSTRI TERHADAP PENINGKATAN KETEGUHAN REKAT KAYU LAPIS
}

\author{
Fauziati *)
}

ABSTRACT

\begin{abstract}
The influence of the substitution of rice husk flour and cassava flour in industrial flour to the increase of plywood bonding strength. The research of the addition of rice hush flour to substitute industrial flour in plywood glueing has been done. A preliminary research has specified the property of industrial flour needed as an extender in a plywood glueing and the role of rice hush flour and cassava flour in that process. Some parameters such as the content of carbohydrate, lignin, moisture, particle size and ash had been tested. The aim of this research is to substitute industrial flour with rice husk flour. Based on the previous research, cassava flour can substitute industrial flour with ratio $60: 40$ and $50: 50$. In this research, rice husk flour has been used to substitute the proportion of cassava flour in that two ratios above. Another inggridients in the used glueing formula were industrial flour, cassava flour, urea formaldehyde, hardener, and veneer from Meranti (B1) and Kapur (B2). The result of this research shows that the content of lignin, cellulose and carbohydrate of rice husk was high enough to influence the process of plywood glueing. The result of all delamination testing were passed or $100 \%$ of all specimen passed delamination testing.
\end{abstract}

Keywords : rice hush flour, cassava flour,plywood glueing, industrial flour

\section{PENDAHULUAN}

7 epung industri adalah tepung terigu kualitas rendah yang digunakan sebagai bahan ekstender dan merupakan komoditi impor yang fungsinya untuk memperbaiki sifatsifat perekat yang ditambahkan dalam adonan perekat kayu lapis untuk memperbaiki sifat perekat itu sendiri, untuk memenuhi permintaan substrat kayu dalam perekatan dan menurunkan biaya atau harga adonan perekat persatuan berat (Skeist,1977).

Formulasi perekat kayu lapis terdiri dari urea formaldehid, Ekstender (termasuk tepung industri) dan hardener (pengeras). Tujuan penggunaan ekstender adalah membantu pengontrolan viskositas adonan perekat, menambah sifat lekat basah (wet tack), mengurangi pelepasan (discharge) bahanbahan pencemar, mengurangi pemakaian perekat murni (seperti resin urea formaldehid), menurunkan biaya perekat dan mengurangi kerusakan garis perekat seperti dry out, crazier dan brittleness.

Sedangkan syarat-syarat bahan dapat digunakan sebagai ekstender yaitu mempunyai sifatsifat perekat, dapat dipecah dan ditumbuk sampai halus sehingga tidak menimbulkan kesulitan dalam pembuatan adonan perekat seperti penggumpalan bahan, seragam /uniform, kadar protein maksimal $10 \%$, kadar abu maksimum $0,55 \%$ pH 6; ukuran partikel $95 \%$ lolos 100 sampai 200 mesh, mempunyai stabilitas viscositas, kadar serat rendah dan tingkat penyerapan air rendah 1:1.

Robertson (1967) dalam Skeist (1977) mengelompokkan sumber bahan ekstender kedalam 3 (tiga) kelompok yakni : Kelompok cereal gluteneous, bahan ini berasal dari kelompok wheat (gandum) ;kelompok cereal non glutienous, bahan ini berasal dari kelompok rye, sorgum, kedelai dan sebagainya (termasuk tepung cassava); kelompok non glutienous non cereal (bahan ini berasal dari bahan kasar yang ditepungkan termasuk sekam padi).

Padi(Oriza sativa) merupakan salah satu sumber karbohidrat, bila dilihat dari konversi padi 
Untuk gabah kering $85 \%$, kandungan berasnya sebesar $50-55$ persen, dedak kasar 7 persen, dedak halus 4 persen dan sekam 24 persen jadi volume sekam padi lebih besar dari pada dedak (Anonim, 1993).

Menurut Ruiten, V (1981) dalam anonim ( 1995 ), prosentase sekam padi terhadap berat gabah adalah 14-26 persen (tergantung varitasnya), kadar air 9,020 persen, protein kasar 3,02 persen, serat kasar 35,68 persen ,karbohidrat 33,71 persen dan kadar abu 17,71 persen. Berdasarkan hasil penelitian menunjukkan bahwa kadar lignin tepung sekam padi sebesar 33,95 persen, sellulose 35,28 persen.

Tolok ukur keteguhan rekat kayu merupakan tolok ukur yang utama dan perlu dalam analisa keberhasilan perekatan. Ini merupakan nilai kekuatan tarik (dengan menggunakan mesin penguji atau universal testing machine) yang mampu dicapai atau dipertahankan oleh papan yang direkatkan. Pengukuran ini dikerjakan menurut tiga kondisi yaitu kondisi kering angin sesuai dengan daerah setempat dilakukan percobaan atau produksi. Kondisi kedua adalah kondisi basah yang dalam prosedur disebut dengan hot cold sak test, sedangkan kondisi ke tiga adalah kondisi basah yang dalam prosedur disebut cycling boiling test. Beberapa modifikasi kondisi pengukuran dilakukan dibeberapa pusat penelitian dengan maksud penyesuaian permintaan setempat. Oleh karena pengukuran keteguhan rekat diharuskan selalu menyatakan kondisi pengukuran .

Nilai keteguhan rekat diukur dalam unit psi (pound per squere inch) atau $\mathrm{kg} / \mathrm{cm}^{2}$. Nilai ini bisa ditelusuri lebih dalam dan dijabarkan kedalam nilainilai dari ketiga macam penyusun perekatan papan, ketiga nilai tersebut adalah nilai kekuatan kohesif dari molekul-molekul kayu/substrat, nilai kekuatan kohesif dari molekul-molekul perekat dan Nilai kekuatan adhesif dari molekul-molekul perekat dengan kayu atau substrat.

Nilai keteguhan rekat tergantung kepada phenomenaphenomena pada garis perekat sewaktu papan yang direkatkan telah melampaui nilai maksimal keteguhan rekat yang mampu dipertahankan olehnya. Sebagai contoh nilai keteguhan rekat $10 \mathrm{~kg} / \mathrm{cm}^{2}$ dicapai oleh plywood tiga lapis dengan ketebalan $1 \mathrm{~cm}$, kondisi kering angin, kerusakan terjadi pada garis perekat.

Dari pernyataan diatas analisa yang mampu dikerjakan adalah bahwa garis perekat merupakan titik terlemah pada komposisi plywood tersebut sehingga pada pengukuran keteguhan rekat berakhir pada kerusakan daerah tersebut. Kekuatan sebesar $10 \mathrm{~kg} / \mathrm{cm}^{2}$ merupakan kekuatan maksimal dari perekat, sehingga ini merupakan nilai kohesif perekat.

Dilain pihak persentase kerusakan kayu atau percentage wood failure merupakan nilai penunjang dalam analisa keteguhan rekat. persentase kerusakan kayu tidak bisa berdiri sendiri sampai tolok ukur perekatan, tetapi harus menyertai nilai keteguhan rekat seperti yang tercantum pada standardisasi kekuatan perekatan plywood di Indonesia maupun ASEAN.

\section{BAHAN DAN METODE \\ Bahan dan Peralatan}

Bahan yang digunakan untuk penelitian ini adalah Tepung industri, tepung cassava, tepung sekam padi, urea formaldehid, $\mathrm{NH} 4 \mathrm{CL}$ dan vinir (jenis meranti dan kapur). Alat yang digunakan meliputi mixer, timbangan analitik, ayakan, universal testing, viscotester.

\section{Metode}

Metode yang digunakan dalam penelitian ini adalah dengan menggunakan basis formulasi ekstender yang digunakan oleh industri perekat kayu lapis yaitu Urea Formaldehid 78-80 $\%$, Ekstender $17-19 \%, \mathrm{NH} 4 \mathrm{Cl}$ (Hardener) 0,5-1\%. Kemudian dibuat variasi campuran ekstender antara tepung industri dan tepung cassava dan tepung sekam padi pada 6 (enam formula). Variasi campuran ekstender tersebut dibuat berdasarkan hasil penelitian Fauziati dan Purwanti,T. (2003) yaitu formulasi campuran ekstender antara tepung industri dan tepung cassava dengan hasil paling optimal (baik) yaitu 60:40\% dengan penambahan air untuk mendapatkan viscositas yang dipersyaratkan (18-22 poise), dan perbandingan 50:50 (\%) tanpa penambahan air.

Berdasarkan kedua perbandingan formulasi tersebut kemudian dibuat perbandingan campuran tepung industri (komposisi konstan) dan tepung cassava serta tepung sekam padi sebagai variabel pada Tabel 1 dan Tabel 2. 
Tabel 1. Perbandingan campuran tepung industri, tepung cassava dan tepung sekam padi dengan basis $60: 40(\%)$.

\begin{tabular}{|c|c|c|c|c|c|c|}
\hline \multirow{3}{*}{ No. } & \multirow{2}{*}{\multicolumn{2}{|c|}{ Tepung Industri }} & \multicolumn{4}{|c|}{$\begin{array}{c}\text { Campuran Tepung Cassava dan Tepung } \\
\text { Sekam Padi }\end{array}$} \\
\hline & & & \multicolumn{2}{|c|}{ Tepung Cassava } & \multicolumn{2}{|c|}{ Tepung Sekam Padi } \\
\hline & $(\%)$ & Gram & $(\%)$ & Gram & $(\%)$ & Gram \\
\hline 1 & 60 & 75 & 32 & 40 & 8 & 10 \\
\hline 2 & 60 & 75 & 24 & 30 & 16 & 20 \\
\hline 3 & 60 & 75 & 20 & 25 & 20 & 25 \\
\hline 4 & 60 & 75 & 16 & 20 & 24 & 30 \\
\hline 5 & 60 & 75 & 8 & 10 & 32 & 40 \\
\hline 6 & 60 & 75 & 0 & 0 & 40 & 50 \\
\hline
\end{tabular}

Tabel 2. Perbandingan campuran tepung industri, tepung cassava dan tepung sekam padi dengan basis $50 \%$ tepung industri dan $50 \%$ tepung cassava dan tepung sekam padi.

\begin{tabular}{|c|c|c|c|c|c|c|}
\hline \multirow{3}{*}{ No. } & \multirow{2}{*}{\multicolumn{2}{|c|}{ Tepung Industri }} & \multicolumn{4}{|c|}{$\begin{array}{c}\text { Campuran Tepung Cassava dan Tepung } \\
\text { Sekam Padi }\end{array}$} \\
\hline & & & \multicolumn{2}{|c|}{ Tepung Cassava } & \multicolumn{2}{|c|}{ Tepung Sekam Padi } \\
\hline & $(\%)$ & Gram & $(\%)$ & Gram & (\%) & Gram \\
\hline 1 & 50 & 65.1 & 40 & 52.08 & 10 & 13.02 \\
\hline 2 & 50 & 65.1 & 30 & 39.06 & 20 & 26.04 \\
\hline 3 & 50 & 65.1 & 25 & 32.55 & 25 & 32.55 \\
\hline 4 & 50 & 65.1 & 20 & 26.04 & 30 & 39.06 \\
\hline 5 & 50 & 65.1 & 10 & 13.02 & 40 & 52.08 \\
\hline 6 & 50 & 65.1 & 0 & 0 & 50 & 60.1 \\
\hline
\end{tabular}

\section{Prosedur Aplikasi pada Kayu Lapis}

1. Jumlah bahan yang digunakan dalam setiap percobaan sesuai dengan perbandingan bahan yang telah ditetapkan dalam metode penelitian.

2. Bahan-bahan urea formaldehid, tepung industri, tepung cassava, tepung sekam padi dan $\mathrm{NH} 4 \mathrm{Cl}$ ditimbang menurut kebutuhan masing-masing campuran.

3. Bahan yang telah siap, dicampur kemudian diaduk dengan mixer sampai homogen selama 15 menit.

4. Selanjutnya diukur viscositasnya dengan alat viscotester.

Kayu lapis dibuat sebanyak 3 (tiga) lapis dengan menggunakan 2 (dua) jenis kayu masing-

masing terdiri dari :

1. Jenis kayu meranti merah dengan ukuran $1 / 24$ inch untuk faceback dan meranti merah $1 / 13$ inch inch untuk core (B1).

2. Jenis kayu kapur dengan ukuran $1 / 24$ inch untuk faceback dan $1 / 13$ inch untuk core (B2). Dari kedua jenis kayu diatas dilakukan uji aplikasi dengan menggunakan formula perekat yang telah ditentukan pada metode penelitian.

3. Vinir dengan ukuran $30 \times 30 \mathrm{~cm}$ ditaburkan perekat sebanyak $29-31 \mathrm{gram} / \mathrm{ft}^{2}$, sebanyak 3 (tiga) lapis ,kemudian dikempa dingin selama 25 menit, dengan tekanan $10 \mathrm{Kg} / \mathrm{cm}^{2}$ selanjutnya dikempa panas pada suhu $100-115 \mathrm{C}$ selama 2 menit pada tekanan $10 \mathrm{Kg} / \mathrm{cm}^{2}$.

Untuk pengujian keteguhan rekat kayu lapis sesuai dengan pengujian perekat tipe I (interior) dengan menggunakan standar Jepang (JIS 1973) sebagai berikut:

1. Contoh uji dibuat dengan ukuran $10 \times 25 \mathrm{~cm}$ direbus dalam air mendidih selama 4 jam.

2. Kemudian dikeringkan dalam oven $60 \mathrm{C} \pm 3 \mathrm{C}$ selama 20 jam 
3. Contoh uji direbus dalam air mendidih selama 4 jam

4. Contoh uji dicelupkan dalam air dingin sampai suhu kamar

5. Contoh uji tersebut diuji dengan alat uji rekat pada waktu masih basah

6. Ketentuan lulus uji bila hasil pengujian minimum $7 \mathrm{~kg} / \mathrm{cm}^{2}$ dan minimum $90 \%$ dari total sampel pengujian.

Untuk pengujian delaminasi menggunakan standar Jepang (JIS-1973) dengan prosedur sebagai berikut:

1. Contoh uji direndam dalam air panas dengan suhu $70 \pm 3 \mathrm{C}$ selama $2 \mathrm{jam}$

2. Contoh uji dikeringkan dalam oven dengan suhu $60 \pm 3 \mathrm{C}$ selama 3 jam

3. Contoh uji diukur lebarnya, panjang dan yang terdeleminasi. Dengan ketentuan bagian yang tidak terdeliminasi tidak boleh kurang dari $50 \mathrm{~mm}$ pada masing-masing sisi permukaan.

\section{HASIL DAN PEMBAHASAN}

Hasil analisis tepung industri, tepung cassava dan tepung sekam padi seperti pada

Tabel 3 .

\begin{tabular}{|c|l|c|c|c|c|}
\hline No. & Parameter & Satuan & $\begin{array}{c}\text { Tepung } \\
\text { Cassava }\end{array}$ & $\begin{array}{c}\text { Sekam } \\
\text { Padi }\end{array}$ & $\begin{array}{c}\text { Tepung } \\
\text { Industri }\end{array}$ \\
\hline 1 & Kadar Air & $\% \mathrm{~b} / \mathrm{b}$ & 7.47 & 7.61 & 9.89 \\
\hline 2 & Kadar Abu & $\% \mathrm{~b} / \mathrm{b}$ & 1.75 & 21.98 & 2.68 \\
\hline 3 & Protein & $\% \mathrm{~b} / \mathrm{b}$ & 2.18 & 4.38 & 2.68 \\
\hline 4 & Karbohidrat & $\% \mathrm{~b} / \mathrm{b}$ & 64.04 & 15.78 & 2.63 \\
\hline 5 & Serat Kasar & $\% \mathrm{~b} / \mathrm{b}$ & 8.72 & 37.18 & 28.85 \\
\hline 6 & $\begin{array}{l}\text { Derajad } \\
\text { Keasaman }\end{array}$ & $\begin{array}{c}\mathrm{Mol} \mathrm{N} \\
\mathrm{NaOH} \\
100 \mathrm{gram}\end{array}$ & 2,03 & 0.98 & 1.35 \\
\hline 7 & Kehalusan & $\begin{array}{c}\% \text { lolos } \\
\text { ayakan } \\
100 \mathrm{mesh}\end{array}$ & 100 & 100 & $\begin{array}{c}\text { Sesuai } \\
\text { ketentuan } \\
\text { pabrik }\end{array}$ \\
\hline 8 & Lignin & $\%$ & 2.78 & 33.95 & 5.35 \\
\hline 9 & Holo selulose & $\%$ & 26.34 & 46.32 & 35.34 \\
\hline 10 & Selulose & $\%$ & 11.63 & 35.28 & 13.65 \\
\hline
\end{tabular}

Sumber : Laboratorium Uji Baristand Industri Samarinda

Parameter uji tepung industri yang dipersyaratkan oleh pihak pabrik perekat kayu lapis di Samarinda adalah kadar air dan kehalusan butiran. Kadar air yang dianjurkan maksimum $15 \%$ dan Kehalusan butiran adalah 100 mesh sebanyak $100 \%$. Kadar air dan kehalusan untuk tepung cassava dan tepung sekam padi Tabel 3 adalah memenuhi syarat sesuai yang dipersyaratkan.

Pada tabel 3 menunjukkan bahwa hasil analisis kandungan lignin, selulose dan karbohidrat yang mempunyai peranan terhadap fungsi perekatan (sebagai ekstender) pada tepung sekam padi adalah cukup tinggi. Ikatan kimia antara lignin dan karbohidrat atau disebut dengan LCC (lignin carbohidrat cellulose) digunakan untuk agregat-agregat yang terikat secara kovalen dan ikatan ikatan glikosida merupakan penyatu lignin dan polisakarida.

Didalam rantai sellulose mempunyai tiga gugus hidroksil yang reaktif yaitu dua sekunder ( $\mathrm{HO}-2$ dan $\mathrm{HO}-3$ ) dan satu primer pada $\mathrm{HO}-6$, adanya ikatan antara lignin dan sellulose dapat berupa tipe ester atau eter dan bahkan glikosida.

Gugus $\mathrm{HO}-2$ mudah teresterifikasi dan gugus $\mathrm{HO}-6$ mudah teresterifikasi sehingga memiliki reaktifitas yang tinggi (Sjosrom, E., 1995). Adanya ikatan antara ligninkarbohidrat dan ligninsellulose tersebut didalam tepung sekam padi khususnya yang merupakan subtitusi tepung industri dan berfungsi sebagai ekstender pada perekat kayu lapis tipe 2 cenderung akan 
memperkuat fungsi perekat glue mix. Bahkan lignin bisa dikatakan sebagai semen penyatu antara molekul-molekul tersebut (Widjaja, R., 1975) yang akhirnya dapat mengurangi penggunaan resin urea formaldehid dan menyempurnakan proses perekatan.

Komposisi formula glue mix A1 perbandingan tepung industri : tepung cassava 60 : $40 \%$ (sebagai acuan penelitian) dan hasil uji keteguhan rekatnya dapat dilihat pada Tabel 4. dan Tabel 5.

Tabel 4 . Komposisi formula glue mix (A,).

\begin{tabular}{|l|c|c|c|c|c|c|c|c|}
\hline \multicolumn{1}{|c|}{ Jenis Bahan } & Satuan & $\mathrm{A} 1.0$ & $\mathrm{~A} 1.1$ & $\mathrm{~A} 1.2$ & $\mathrm{~A} 1.3$ & $\mathrm{~A} 1.4$ & $\mathrm{~A} 1.5$ & $\mathrm{~A} 1.6$ \\
\hline Urea Formaldehid & $(\mathrm{g})$ & 575 & 575 & 575 & 575 & 575 & 575 & 575 \\
\hline Tepung Industri & $(\mathrm{g})$ & 75 & 75 & 75 & 75 & 75 & 75 & 75 \\
\hline Tepung cassava & $(\mathrm{g})$ & 50 & 40 & 30 & 25 & 20 & 10 & 0 \\
\hline $\begin{array}{l}\text { Tepung sekam } \\
\text { padi }\end{array}$ & $(\mathrm{g})$ & 0 & 10 & 20 & 25 & 30 & 40 & 50 \\
\hline Hardener $(\mathrm{NH4Cl})$ & $(\mathrm{g})$ & 5 & 5 & 5 & 5 & 5 & 5 & 5 \\
\hline Air & $(\mathrm{g})$ & 25 & 10.5 & 20 & 22.1 & 25 & 25 & 12.5 \\
\hline Jumlah & $(\mathrm{g})$ & 730 & 715.5 & 725 & 727.1 & 730 & 717.5 & 717.5 \\
\hline pH & & 5.8 & 6.77 & 6.16 & 6.55 & 6.08 & 5.7 & 5.84 \\
\hline Viscositas & poise & 18.5 & 20.55 & 22 & 21 & 19.5 & 21.75 & 22.5 \\
\hline $\begin{array}{l}\text { Tepung industri : } \\
\text { (T.cassava : T } \\
\text { Sekam padi) }\end{array}$ & $\%$ & $60: 40: 00$ & $60: 32: 08$ & $60: 24: 16$ & $60: 20: 20$ & $60: 16: 24$ & $60: 08: 32$ & $60: 00: 40$ \\
\hline
\end{tabular}

Catatan :

$A_{1 \cdot 0}=$ formula glue mix yang digunakan sebagai acuan pada penelitian ini

$A_{1}=$ Perbandingan formulasi glue mix tepung industri : tepung cassava

Pada formula glue mix viscositas dan $\mathrm{pH}$ berpengaruh terhadap proses perekatan, viscositas yang dipersyaratkan pada formula glue mix sebelum dilaburkan pada vinir sebesar $18-22,50$ poise, sedangkan $\mathrm{pH}$ adalah sebesar 5,0 sampai dengan dibawah 7,0 .

Pada tabel 4. menunjukkan bahwa viscositas awal formula glue mix A1.1 sampai dengan A1,6 memenuhi syarat yang berkisar antara $19,5-22,5$ poise, namun viscositas awal tersebut rata-rata diatas 20,0 poise yang akan berpengaruh terhadap "Pot Life" (waktu perekatan) menjadi lebih pendek. Waktu perekatan yang terbaik maksimum 5,0 jam masih memenuhi syarat dengan viscositas maksimum 22,50 poise.

Sedangkan $\mathrm{pH}$ berpengaruh terhadap viscositas dimana $\mathrm{pH}$ tersebut masih dalam batas standar yang dipersyaratkan .

Pada komposisi formula glue mix A1.1 sampai A1.6 semuanya memerlukan air yang relatif besar dalam proses formulasinya, hal tersebut akan mempengaruhi formula glue mix yaitu adanya kecenderungan terjadi pengendapan selama waktu perekatan terhadap kayu lapis ,sehingga kemungkinan terjadinya ketidak sempurnaan dalam proses perekatan . walaupun disisi lain akan mengurangi penggunaan bahan-bahan perekat. Batas maksimum penambahan air adalah 25 gram dan bahan yang digunakan sebagai ekstender terbaik mempunyai tingkat penyerapan rendah (Skeist,1977).

Pada lampiran 1 menunjukkan bahwa hasil uji keteguhan rekat $A 1$ untuk semua formulasi dari A1.1 sampai dengan A1.6 memenuhi syarat kelulusan $100 \%$ keteguhan rekat dan uji deliminasi untuk semua jenis kayu Baik B1 (Kayu meranti merah) maupun B2 (Kayu kapur).

Komposisi formula glue mix A2 dapat dilihat pada tabel 5 . dan hasil analisa keteguhan rekat A2 dapat dilihat pada lampiran 2. 
Tabel 5 . Komposisi formula glue mix (A2)

\begin{tabular}{|l|c|c|c|c|c|c|c|c|}
\hline \multicolumn{1}{|c|}{ Jenis Bahan } & Satuan & A2.0 & A2.1 & A2.2 & A2.3 & A2.4 & A2.5 & A2.6 \\
\hline Urea Formaldehid & $(\mathrm{g})$ & 575 & 575 & 575 & 575 & 575 & 575 & 575 \\
\hline Tepung Industri & $(\mathrm{g})$ & 65.1 & 65.1 & 65.1 & 65.1 & 65.1 & 65.1 & 65.1 \\
\hline Tepung Cassava & $(\mathrm{g})$ & 65.1 & 52.08 & 39.06 & 32.55 & 39.06 & 52.08 & 65.1 \\
\hline $\begin{array}{l}\text { Tepung Sekam } \\
\text { Padi }\end{array}$ & $(\mathrm{g})$ & 0 & 13.02 & 26.04 & 32.55 & 39.06 & 52.08 & 65.1 \\
\hline Hardener & $(\mathrm{g})$ & 5 & 5 & 5 & 5 & 5 & 5 & 5 \\
\hline Air & $(\mathrm{g})$ & 0 & 0 & 0 & 0 & 0 & 0 & 0 \\
\hline Jumlah & $(\mathrm{g})$ & 710.2 & 710.2 & 710.2 & 710.2 & 722.7 & 710.2 & 724.8 \\
\hline $\begin{array}{l}\text { Ph } \\
\text { Viscositas }\end{array}$ & - & 5.65 & 5.75 & 5.6 & 5.8 & 6.08 & 5.5 & 5.79 \\
\hline $\begin{array}{l}\text { T. Industri :T } \\
\text { Cassava: } \\
\text { T.Sekam padi }\end{array}$ & 18.5 & 18 & 20.5 & 18 & 19.5 & 19 & 20 \\
\hline
\end{tabular}

Catatan :

A2.0 = Formula glue mix yang digunakan sebagai acuan pada penelitian ini.

A2 = Perbandingan formulasi glue mix tp industri :tp cassava $50: 50$

Pada tabel 5 menunjukkan bahwa viscositas awal formula glue mix A2 dari A2.1 sampai dengan A2.6 memenuhi syarat berkisar antara 18,0 sampai dengan 20,5 poise, relative lebih kecil dari pada formula $\mathrm{A} 1$, waktu proses perekatan (Pot Life) selama 5 jam sehingga proses perekatan menjadi lebih sempurna.

Pada formula $A 2$ penambahan air relatif sedikit dibanding formula $A 1$, dengan menggunakan tepung industri lebih sedikit yaitu sebanyak $50 \%$, dan $50 \%$ berikutnya adalah subtitusi dari tepung cassava dan tepung sekam padi. Keteguhan rekat dan delaminasi formula A2.1 sampai dengan A2.6 memenuhi syarat kelulusan $100 \%$ baik untuk jenis kayu B1 (meranti merah) maupun B2 (Kayu kapur). Komposisi paling optimum pada formula glue mix A2.6B1 dan A2.6 B2 dengan nilai keteguhan rekat maksimum $23,4 \mathrm{~kg} / \mathrm{cm}^{2}$ dan minimal $11,9 \mathrm{~kg} / \mathrm{cm}^{2}$.

Dengan kuantitas tepung sekam padi yang paling maksimum pada formulasi glue mix tersebut memberikan hasil yang paling optimum pada keteguhan rekat maupun delaminasinya. $\mathrm{Hal}$ tersebut terjadi karena tepung sekam padi mempunyainkandungan lignin, karbohidrat dan sellulose cukup tinggi dimana adanya ikatan kovalen antara lignin dan karbohidrat dan adanya gaya assosiasi secara fisika yang disebut dengan komplek ligninkarbohidrat yang digunakan sebagai agregat yang terikat secara kovalen. Dan ikatan-ikatan yang terjadi antara lignin dan sellulose berupa ester atau glikosida.

Fungsi kandungan lignin tersebut mempunyai peranan sebagai penyatu sel-sel (molekul) terhadap kekuatan kohesif didalam senyawa perekat dan kekuatan adhesif antara molekulmolekul perekat dan sel kayu, dimana sel kayu mempunyai kandungan sellulose, karbohidrat dan lignin yang cukup tinggi pula.

\section{KESIMPULAN}

Dari hasil pembahasan dapat disimpulkan formula A1 (perbandingan formula glue mix tepung industri : tepung cassava 40:60) dan formula A2 (Perbandingan formula glue mix tepung industri:tepung cassava 50:50\%) semuanya memenuhi syarat kelulusan keteguhan rekat dan uji deliminasi kayu lapis sebesar $100 \%$, dan formula A2 dengan komposisi $50 \%$ tepung industri ,50\% tepung cassava dan tepung sekam padi adalah bentuk formulasi glue mix yang relatif lebih optimum dari pada formulaA1. 


\section{DAFTAR PUSTAKA}

Anonim, 1993. Vadekum Teknologi Pasca Panen dan Pengolahan Hasil Pertanian. Direktorat Jenderal Pertanian dan Tanaman Pangan ,Jakarta.

Fauziati dan Purwanti, T,. 2003. Pemanfaatan Tepung Cassava sebagai Subtitusi Tepung Industri pada perekat kayu lapis .BPPI Samarinda.

Wijaya, M.R. . 1975. Industri Perkayuan Proyek Penyuluhan dan Promosi Hasil Industri. Ditjen Aneka Industri dan Kerajinan Departemen Perindustrian .Jakarta

Sjostrom E, 1995. Kimia Kayu Dasar dasar dan Penggunaan Edisi 2 ,Gajah Mada University Press . Yogyakarta.

Skeist, 1977, Hand book of Adhesive. Van Nostrand Reinhold Company New York. 
Lampiran 1

Hasil Uji Keteguhan Rekat (A1)

\begin{tabular}{|c|c|c|c|c|c|c|c|c|c|c|c|c|c|c|}
\hline \multirow{2}{*}{ o } & \multicolumn{2}{|c|}{ Formula A 1.0} & \multicolumn{2}{|c|}{ Formula A1.1 1} & \multicolumn{2}{|c|}{ Formula A1.2 } & \multicolumn{2}{|c|}{ Formula A1.3 } & \multicolumn{2}{|c|}{ Formula A1.4 } & \multicolumn{2}{|c|}{ Formula A1.5 } & \multicolumn{2}{|c|}{ Formula A1.6 } \\
\hline & B1 & B2 & B1 & B2 & B1 & B2 & B1 & B2 & B1 & B2 & B1 & B2 & B1 & B2 \\
\hline 1 & 7.8 & 13.6 & 13.8 & 10.8 & 11.5 & 12.3 & 13.6 & 16 & 9.7 & 9.3 & 11.5 & 13.8 & 12.6 & 16.4 \\
\hline 2 & 11.6 & 10.9 & 13.4 & 15.3 & 12.6 & 11.9 & 11.5 & 13.4 & 8.2 & 16.4 & 12.3 & 14.1 & 14.5 & 15.6 \\
\hline 3 & 10.4 & 13.1 & 11.2 & 16.7 & 14.9 & 13.4 & 13.8 & 19 & 18.2 & 17.1 & 13.4 & 12.6 & 13.6 & 17.5 \\
\hline 4 & 8 & 11.8 & 14.5 & 17.1 & 13 & 12.6 & 14.9 & 17.1 & 18.2 & 16.7 & 16.4 & 8.9 & 11.9 & 17.1 \\
\hline 5 & 8.5 & 13.8 & 12.6 & 18.6 & 14.5 & 11.5 & 11.9 & 19.7 & 10.4 & 17.3 & 11.9 & 11.9 & 14.9 & 15.6 \\
\hline 6 & 5.5 & 13.8 & 11.9 & 13 & 12.6 & 19.3 & 12.6 & 10.8 & 10 & 16.4 & 16.4 & 20.5 & 12.6 & 12.6 \\
\hline 7 & 7 & 11.8 & 14.1 & 10.8 & 11.5 & 11.9 & 17.5 & 16.7 & 15.3 & 10.8 & 15.6 & 16.7 & 11.9 & 14.9 \\
\hline 8 & 10.9 & 13.5 & 15.3 & 14.1 & 13 & 13.8 & 9.3 & 16 & 15.3 & 12.4 & 16.4 & 18.6 & 13.8 & 14.1 \\
\hline 9 & 7.8 & 14 & 12.3 & 17.5 & 11.9 & 14.9 & 12.6 & 19.3 & 11.2 & 16.4 & 12.3 & 17.5 & 13.4 & 14.9 \\
\hline 10 & 13 & 14.2 & 12.3 & 14.9 & 13 & 17.5 & 13.8 & 16.7 & 10.8 & 8.2 & 12.6 & 20.1 & 9.9 & 16.4 \\
\hline 11 & 9.7 & 18.4 & 16.1 & 15.3 & 17.6 & 16.4 & 14.4 & 16 & 14.9 & 13.4 & 15.6 & 20.1 & 13.8 & 19.7 \\
\hline 12 & 10.9 & 16.7 & 16.4 & 15.3 & 14.1 & 17.9 & 13.8 & 17.7 & 18.2 & 16.9 & 14.5 & 17.1 & 13.8 & 14.5 \\
\hline 13 & 14,3 & 16.5 & 11.5 & 17.7 & 11.5 & 15.6 & 11.5 & 19.3 & 12.3 & 17.1 & 11.2 & 13.4 & 11.9 & 18.2 \\
\hline 14 & 9.7 & 14.3 & 13.8 & 17.1 & 13 & 17.5 & 12.3 & 16.7 & 11.7 & 16.7 & 14.5 & 16.4 & 11.5 & 16.4 \\
\hline 15 & 11.9 & 14.7 & 13.4 & 20.1 & 13 & 17.9 & 14.9 & 17.9 & 13.4 & 9.3 & 14.1 & 16.7 & 12.8 & 14.1 \\
\hline Maks & 14.3 & 18.4 & 16.4 & 21.1 & 14.9 & 17.9 & 14,9 & 19.7 & 18.2 & 17.1 & 16.4 & 20.5 & 14.9 & 18.2 \\
\hline Min & 5.5 & 10.9 & 11.2 & 10.8 & 11.5 & 11.5 & 9.3 & 10.8 & 8.2 & 8.2 & 11.2 & 8.9 & 7.7 & 9.7 \\
\hline Rata-rata & 9.8 & 14.1 & 13.4 & 15.6 & 12.9 & 14.3 & 13.2 & 16.8 & 13.1 & 14 & 13.9 & 15.9 & 12.9 & 15.2 \\
\hline elulusan & $93 \%$ & $100 \%$ & $100 \%$ & $100 \%$ & $100 \%$ & $100 \%$ & $100 \%$ & $100 \%$ & $100 \%$ & $100 \%$ & $100 \%$ & $100 \%$ & $100 \%$ & $100 \%$ \\
\hline
\end{tabular}

Uji Deliminasi $100 \%$

Lampiran 2

Hasil Uji Keteguhan Rekat (A2)

\begin{tabular}{|c|c|c|c|c|c|c|c|c|c|c|c|c|c|c|}
\hline \multirow{2}{*}{ No. } & \multicolumn{2}{|c|}{ Formula A2.0 } & \multicolumn{2}{|c|}{ Formula A2.1 } & \multicolumn{2}{|c|}{ Formula A.2.2 } & \multicolumn{2}{|c|}{ Formula A2.3 } & \multicolumn{2}{|c|}{ Formula A2.4 } & \multicolumn{2}{|c|}{ Formula A2.5 } & \multicolumn{2}{|c|}{ Formula A2. } \\
\hline & B1 & B2 & B1 & B2 & B1 & B2 & B1 & B2 & B1 & B2 & B1 & B2 & B1 & $\mathrm{B} 2$ \\
\hline 1 & 8.7 & 11.2 & 14.1 & 14.1 & 11.9 & 11.2 & 10.4 & 12.8 & 13.8 & 16.1 & 18.2 & 20.5 & 14.5 & 19 \\
\hline 2 & 8.9 & 9.2 & 12.3 & 17.5 & 11.9 & 10 & 14.5 & 17.9 & 13 & 14.9 & 16.7 & 16.4 & 13.4 & 23.4 \\
\hline 3 & 9.5 & 10.4 & 15.6 & 16 & 18.3 & 16 & 12.6 & 12.6 & 8.9 & 20.8 & 16 & 14.1 & 13.8 & 16 \\
\hline 4 & 13.8 & 12.3 & 16.4 & 13.8 & 12.3 & 17.9 & 16 & 19.7 & 10.4 & 16 & 15.6 & 17.5 & 13.4 & 21.2 \\
\hline 5 & 9.5 & 10.4 & 15.6 & 14.9 & 13 & 16 & 15.6 & 17.9 & 10 & 17 & 15.6 & 17.1 & 13.8 & 20.1 \\
\hline 6 & 10.6 & 14.3 & 14.5 & 18.6 & 14.6 & 14.9 & 12.3 & 19.7 & 11.9 & 13.4 & 17.1 & 17.1 & 13 & 20.8 \\
\hline 7 & 11.1 & 11.2 & 16.4 & 13 & 15.3 & 16.7 & 11.9 & 21.5 & 15.3 & 18.2 & 15.6 & 15.6 & 19.7 & 13 \\
\hline 8 & 14.7 & 12.6 & 10 & 11.2 & 13.4 & 16.4 & 15.3 & 15.6 & 13.8 & 18.2 & 13.8 & 17.5 & 11.9 & 14.5 \\
\hline 9 & 9.4 & 11.2 & 16.4 & 11.9 & 13.4 & 15.3 & 14.1 & 14.5 & 14.9 & 17.9 & 20.1 & 15.6 & 15.6 & 21.1 \\
\hline 10 & 11.6 & 13.5 & 13.8 & 15.3 & 14.5 & 13 & 13.8 & 17.1 & 10.4 & 16 & 16.9 & 16 & 12.6 & 23.1 \\
\hline 11 & 12.9 & 12.8 & 16 & 16 & 13.8 & 14.5 & 13.8 & 20.5 & 11.2 & 14.1 & 18.6 & 17.1 & 12.3 & 14.5 \\
\hline 12 & 11,2 & 16.4 & 19.3 & 14.9 & 14.9 & 13.4 & 14.9 & 15.3 & 11.2 & 14.1 & 18.6 & 17.1 & 12.3 & 14.5 \\
\hline 13 & 14.1 & 12.3 & 15.6 & 11.2 & 14 & 16.7 & 14.1 & 18.2 & 18.2 & 17.5 & 14.8 & 18.2 & 13.4 & 11.9 \\
\hline 14 & 12.8 & 7 & 14.5 & 17.5 & 14.9 & 7.4 & 13.8 & 17.9 & 12.6 & 18.2 & 15.6 & 17,5 & 14.5 & 16.4 \\
\hline 15 & 13.5 & 15.2 & 17.3 & 18.2 & 11,5 & 12.6 & 13 & 14.5 & 14.1 & 18.6 & 15.3 & 17.3 & 13 & 14.1 \\
\hline Maks & 14.7 & 16.4 & 19.3 & 18.6 & 15.3 & 17.9 & 16 & 21.8 & 15.3 & 20.8 & 20.1 & 20.5 & 19.7 & 23.4 \\
\hline Min & 8.7 & 7 & 1 & 11.2 & 11,5 & 7.4 & 10.4 & 12.6 & 8.9 & 13.4 & 13.8 & 14.1 & 11.9 & 11.9 \\
\hline Rata-rata & 11 & 12 & 14.9 & 14.9 & 13.7 & 14.8 & 14.7 & 17.4 & 12.4 & 17.1 & 16.5 & 17.1 & 14.1 & 17.5 \\
\hline Kelulusan & $100 \%$ & $100 \%$ & $100 \%$ & $100 \%$ & $100 \%$ & $100 \%$ & $100 \%$ & $100 \%$ & $100 \%$ & $100 \%$ & $100 \%$ & $100 \%$ & $100 \%$ & $100 \%$ \\
\hline
\end{tabular}

Uji Deliminasi $100 \%$ 